\title{
A Tsunami-Related Life History of Survivors in Banda Aceh, Indonesia and Sendai, Japan
}

\author{
Agus Suwignyo \\ History Department, Faculty of Cultural Sciences and the Center for Southeast Asian Social Studies, \\ Universitas Gadjah Mada (email: suwignyo_agus@ugm.ac.id)
}

\begin{abstract}
In tsunami risk-reduction programs the survivors' life history provides first-hand information about how they responded during and after a catastrophe. However, knowledge of tsunamirelated experiences is not always systematically managed and institutionally communicated across generations. Some risk reduction programs lack of informed knowledge of tsunami-related experiences and consequently tend to be insensitive towards survivors' life history. The aim of this paper is to examine how tsunami survivors constructed their tsunami-related knowledge and collective memories, taking the cases of Banda Aceh, Indonesia after the 2004 tsunami and Sendai, Japan after the 2011 tsunami. This paper, in particular, seeks to explore how the survivors' experience helped to institutionalize their tsunami-related knowledge in a transferrable riskreduction consciousness. Using first-hand interviews as well as interview recordings which were accessible online, this paper argues that in both cases of tsunami survivor cohorts, knowledge of tsunami-related experience was constructed through survival strategies and recovery processes in the aftermath of the events. Knowledge of survival strategies was constructed over time; and the longer period from the time of event, the more tacit the knowledge was. The process of knowledge construction was systematic in the Sendai case but was vernacular in the Banda Aceh case. However, in both cases the need for more engaged institutional communication between the government agencies and the people was evident.
\end{abstract}

Keywords:

Banda Aceh; life history; Sendai; social development; tsunami risk reduction

\section{Introduction}

Survivors of a catastrophe generally have a better state of preparedness for a future emergency situation related to disaster. Their life history of a previous event helps to mitigate the risk of a future disaster. The knowledge an individual survivor has acquired and constructed of a previous disaster, called prior knowledge of disaster, has contributed to the decision they make in response to a calamity. Taken cumulatively, prior knowledge of a disaster comprises a collective memory by which a community or a cohort of people constructs an institutional knowledge and resilience strategy. A collective memory of a disaster helps a community to set immediate responses during a catastrophic event and in the longer term of its aftermath.

The survivors of the tsunami that hit Aceh on December 26, 2004 provide a valuable set of collective memory, which is relevant for the development of future risk-reduction programs. Unfortunately, when this study was undertaken in 2013 and 2014, they had been touched in passing in the existing studies of the catastrophe. Since those years, there have been a number of studies that explore the 2004 Aceh tsunami from the perspective of its survivors. 
However, only a few of the existing studies have explored how the survivors managed to survive the Aceh tsunami. Generally, the studies which deal with tsunami survivors focus on the survivors' understanding, perception, and individual decisions of escaping the natural hazards. Local knowledge of tsunami has somehow received a little attention from scholars. The author is lucky to find a study by Rahman, Sakurai and Munadi (2018), who examine how the local story of tsunami, called smong, has changed from time to time in the twentieth century because of the different context-specific factors that had surrounded a particular tsunami event.

The aim of this paper is to examine how the survivors of the December 2004 tsunami in Banda Aceh, Indonesia, constructed their knowledge of the catastrophe. In particular, this paper analyzes the life history of the Banda Aceh cohorts of the Aceh tsunami survivors in a comparison to the survivors of the March 2011 tsunami in Sendai, Miyagi Prefecture, Japan. To what extent was the strategy a tsunami survivor adopted influenced or "mitigated" by their prior knowledge about tsunami in both cases of cohorts? The author argues that prior knowledge of tsunamis helped the survivors build a healing collective memory. An organized way of transforming tsunamirelated knowledge from one community or generation to another is thus a prerequisite to the making of tsunami risk-reduction programs.

Indonesia's Aceh tsunami of December 26, 2004 was triggered by a 9.0 magnitude earthquake in the West coast of Sumatra. It caused the death of more than 230,000 people in twelve countries, of whom 170,000 casualties were in the Indonesian province of Aceh. The tsunami that hit the Miyagi prefecture in Japan on March 11, 2011 was stimulated by a 9.0 magnitude undersea earthquake. It killed about 15,760 people and, more seriously, destroyed the nuclear power plants and raised serial threats of disasters in the aftermath. See, for example, Samek, Skole, and Chomentowski (2004); Kingston (2012, pp. 1-11).

The need for a comparison of the Indonesian Aceh's tsunami survivor history to the Japanese Sendai case has owed inspiration to the global frameworks of knowledge and experience sharing of disaster-risk reduction. One of the frameworks was The 5th Asian Ministerial Conference on Disaster Risk Reduction, which was held in the city of Yogyakarta, Indonesia from 22 to 25 October 2012 (UNDRR, 2012). During the conference speakers from across the world spoke of how to strengthen local capacity for disaster risk reduction by sharing and making use of both local and global experiences. For example, Erik Kjaergaard, a Senior Emergency Specialist of the UNICEF, presented a project entitled "Children participation in safe school and inclusive disaster risk education" that suggests that the children participating in the program can develop in themselves an awareness of natural disasters and play a role as effective communicators for their peers. The UNICEF later published a full report of this project (Kjaergaard, 2015).

While the conference promoted crosscultural cooperation in disaster risk-reduction education programs, the participation of survivors indeed received only a little attention in the forum (N.N., 2012, p. 14). This reflects a general void of knowledge in the post-disaster management programs. As anthropologist Schlehe (2010, p. 112) has identified, in many cases of natural disaster relief projects the "dominant discourses emphasize concrete physical aspects," while the "cultural aspects and indigenous concepts which are also part of the local people's attitudes and reactions" are generally set aside. At this very point, Japan, a country with a century of experience in dealing with earthquakes and tsunamis, holds a key role in providing a benchmark for many other countries. 
With the case of the earthquake and tsunami that hit Japan's Miyagi Prefecture on March 11th, 2011 it became obvious that there were country-specific elements related to both the government and the people that determined the recovery processes. These elements significantly had to do with the preparedness the people shared for coping with tsunami-stipulated disaster (N.N., 2013, p. 10).

The quick responses of the Japanese government and people indicated that lessons from past tsunamis were well learnt by both the government and people in mitigating and coping with current natural disasters. As Kawato, Pekkanen and Tsujinaka (2012, p. 78) put it, Japan's civil society, such as neighborhood associations and Non-Profit Organizations (NPOs) "had developed expertise through past disasters." It had, "Before the [March 2011] disaster, improved the preparedness and created social capital that facilitated the response to the disaster." The Japanese people soon analyzed the lessons of the Tohoku catastrophe to provide the public with a systematic knowledge of a particular tsunami event (Veras et al., 2014, pp. 84-108).

In the case of Japanese experience, efforts to involve the survivors' experience in disaster risk reduction and to learn from other survivors' past experience have also been shown by individual initiatives. For example, in October 2012, Yuka Matsumoto and Nayu
Hanii launched the Indonesian language version of a manga, which contains educative messages and practical knowledge on avoiding greater or fatal impact of an earthquake (Arif, 2012, p. 14).

Thus, the responses of the Japanese society to the Sendai tsunami were in many ways different from the responses of the Indonesian society to the Aceh tsunami. Although the two tsunamis were similarly disastrous to the respective countries, more systemic institutional responses of the government and the people can be seen in the Japan case rather than in the Indonesian case. Japan's accumulated knowledge of the past tsunamis had contributed to the creation of a shared consciousness in which both advanced technologies and traditional knowledge sources (literature and tsunami-warning stones) were used in the mitigation programs. A study by Shibata (2012), for example, summarizes different records available about ninth-century tsunamis in Japan and shows that ancient Japanese people wrote poems and folklore to store their collective memories of the catastrophes.

\section{Literature reviews}

There have been relevant literature to set a better understanding of the post-disaster social restructuration. Rofi, Doocy and Robinson (2006), Fitzpatrick (2008), Ehrentraut (2010) and

Picture 1.

Tsunami warning stone tablets in Aneyoshi Japan, as shown by a personal blog (left) and by the New York Times (right)

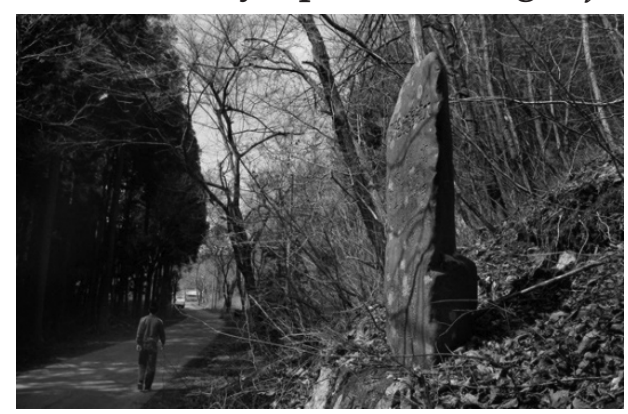

Sources: Fackler (2011); Kohlstedt (2016)

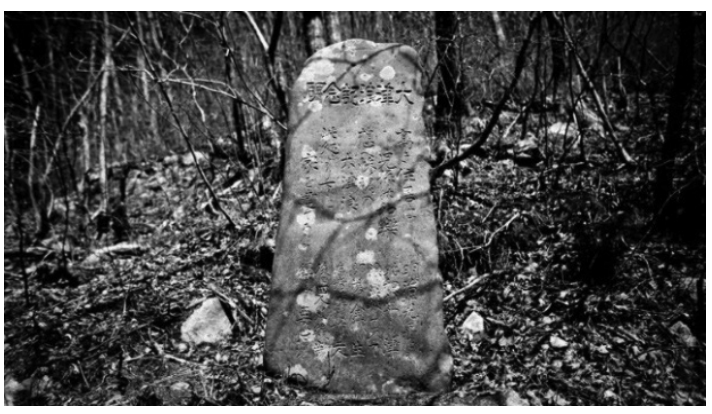


Miller and Bunnel (2011) have examined the impact of the tsunami on the displacement of the Aceh people socially and politically. Other studies have focused on improving people's disaster awareness (Sugimoto, Iemura, \& Shaw, 2010).

Meanwhile, researchers also examine creative ideas of developing risk reduction programs both in the case of tsunami and other disasters. Dudley, Goff and Johnston (2009) and Iemura et al. (2006) work on mapping out the craft knowledge of tsunami survivors and their immediate reactions. Octastefani and Rum (2019) and Lestari, Paripurno and Nugroho (2018) suggest that a risk reduction program be based on expanding the collective capacity of a community while Hidayat (2019) emphasizes the importance of communication among agencies. Among the few studies that deal with the Acehness' prior knowledge of tsunami is the work by McAdoo et al. (2006) on the local oral history of smong, literally meaning "the land swept by seawater." Both McAdoo et al. (2006) and Reid (2015, pp. 88-108) innovatively make use of the sources available of the disaster literacy of the local people.

In this paper, "survival strategy" is understood as a detailed plan for continuing to exist or stay alive in an uncertain condition. While quite thorough, this semantic definition implies the possession of prior knowledge of the plans to be executed during a "high level" situation, such as a disastrous event. As Valent (1998) puts it, there are always precursors to one's decision for a particular action of survival strategy, including adaptation syndromes related to previous experiences, social attachment, and caretaking (p. 2). By defining "survival strategy" as specific stress responses, which include specific adaptive and maladaptive, biological, psychological and social constituents (p. 3), Valent underlines a concept that goes back as far as the Darwinian Theory. Yet, he also emphasizes that someone's response to survive through a stress situation depends on various precursors that are not always instinctive. The precursors to a particular survival strategy action, he argues, have also to do with the cognitive understanding that one has previously acquired on a related crisis situation.

Survival strategy also refers to the process of meaning making that the survivors did of their tsunami-related experiences. This process of meaning making, according to Merli (2010, p. 110), has to be "analyzed in relation to the local context," which "assume[s] a specific meaning [for] a local community and its sense of identity with respect both to other local communities and to other national or extra-national ones." As Schlehe (2010, p. 112) argues, meaning making is a process of "encountering, defining, and adapting to risk and hazards" that is "highly influenced by cultural perceptions and interpretations." And as Gaillard and Texier (2010, p. 82) also argue, "people do not asses risk in simple forms" but balance their assessment in "a large array of losses and benefits for their everyday life" in which social, economic and political as well as religious constraints play role.

Although one's decision for taking or not taking a particular action of survival in a critical situation is individual in nature, the considerations that underline such a decision have a complex social dimension. They can be both cognitive as regards to the acquisition of prior knowledge, and cultural in terms of the external factors that influence or form them. In other words, while it bears biological and instinctive natures as the Darwinian theorists suggest, and although it is always context specific by time and place, survival strategy can be learned, manipulated and improved. It is at this very theoretical point that the survivors' experience has to be considered in a tsunami risk-reduction program. Such an experience also needs to be analyzed in a cross reference to other experiences at different contexts to see any interface of patterns. 
Regardless of the memory questionnaires developed by Iemura et al. (2006) and Dudley, Goff, Chagué-Goff, and Johnston (2009), survivors' prior knowledge of tsunami and their retrospective view of their tsunami experience remained particularly important in the study of collective memory of the survivors. Aspects of education level, occupation, age and sex were determinant in the way the survivors re-constructed their memories (Neumayer \& Plümper, 2007; Chandler, 2005).

\section{Methods}

This study employs three different methods, namely oral history, media recording analysis, and library research. First of all, the interviews were aimed to collect testimonials concerning instinctive development at the individual level of the "early warning mental-system." The data collected from interviews were transcribed. Information resulting from the interviews was classified based on the categories of survival strategies. The information includes the immediate individual responses to earthquake and tsunami signals, culture-based beliefs of the dos and don'ts related to disasters, and how the individual survivors dealt with the aftermath trauma. In total twenty-five persons of randomly selected tsunami survivors in Banda Aceh participated in this study. In contrast, only one survivor of the Sendai tsunami was interviewed, all because of limited access to the Sendai cohorts.

To cover up the balance of survivors' testimonials between both cohorts, this research made use of some interview recordings of the Sendai tsunami and this constituted the second method, namely media recording analysis. The researcher used YouTube to collect any video related to the 2011 Sendai earthquake and tsunami. Of all the Sendai tsunami-related videos seen on YouTube, three were selected because of their comprehensiveness of the stories they contained. Details of the selected videos were presented in the Results section of this article.

Last but not least is the library research method. This method was aimed at collecting printed materials about tsunamis and tsunami survivors both in Indonesia and in Japan. The information emanating from the printed sources was classified into primary and secondary categories. This way the analysis of the survival strategies, or how these had been studied, was determined.

\section{Results}

\section{Previous Knowledge and Patterns of Immediate Responses \\ Banda Aceh Tsunami Survivors}

The Banda Aceh survivors interviewed for this study include 17 males and 8 females. At the time of interview, their age ranged between 20 and 30 years (12 persons); between 31 and 40 years ( 1 person); between 41 and 50 years (7 persons); above 50 years (5 persons). In the current study, these informants are identified by pseudonyms.

Only three of these 25 survivors had ever known about what a tsunami was before the 2004 tsunami event. This influenced so much on the first immediate reaction they took when hearing about seawater rising at the night of the catastrophe on 26 of December, 2004. An informant said:

"When I heard people shouting repeatedly 'The seawater has risen up,' I did not believe it. I said to myself, 'How would it be possible that the seawater rises up far into the land? I never imagined and had never thought about it."' (personal communication, May 10, 2013)

Another informant confirmed those testimonies, saying:

"At that time I put it in a rational way, it was not possible that the seawater comes up to the land. But then I heard elder neighbors of mine shouting the same words. Because 
the elder people already believed it, so did I." (personal communication, May 10, 2013).

Siti (43 years old, female) said she had known the tale of "smong" (the water sweeps the land), but she heard about it after her relative had survived the tsunami in the island of Simeuleu. Siti's testimony confirms the findings of McAdoo et al. (2006), which show that the people of Simeuleu had passed the folklore from one generation to another, but they saw it as a fairytale rather than as a warning system.

Rasyid, who was 15 years old in December 2004, had a different message. In his opinion, the Aceh people knew the word "ibena," which means huge wave (Tedbudiyansah, 2013). Another informant said:

"I had ever heard about tsunami before and had also known what it meant. But I thought it could only happen in Japan!" (personal communication, June 12, 2013)

Hasan (27 years, male) said he knew what a tsunami is but never saw one and thus did not know what to do when the tsunami came. Another informant, who had lived in Banda Aceh for more than six decades, related the tsunami he experienced with a political event. He said:

"The last tsunami in Aceh (before the December 2004 tsunami] hit the Sabang Island. It happened after the DII movement [an Islamist uprising in the 1950s]. Then it became peaceful, but not too long. Then there was another tsunami just before the PKI uprising [Indonesian Communist Party], also in the Sabang Island. It lasted for three months, we were all shaken." (personal communication, June 13, 2013).

Djafri's testimonial, however illogical to some extent it may sound, shows how knowledge of tsunami could be so widely connected to other events of different natures. As anthropologist Schlehe (2010, p. 113) notes, in the Indonesian society in general, "events in nature are seen as being tightly connected to the state of society and political power."

Notwithstanding this, the majority of interviewees also had no cognitive prior about a tsunami even if it was a term of their own cultural folklore. "Knowledge" here means "something that is known" as related to tsunami. But even for such a common sense, the understanding of tsunami that my informants told me does not really makea clear point. Because those informants consist of those who were, in December 2004, both teenagers, adults and elderly people, the absence of knowledge on tsunami was a gross phenomenon of the Banda Aceh cohort of this study. It was not an incidental case.

The absence of prior knowledge on tsunami was somehow reflected in the survivors' decision on escaping the tsunami at the time of the event. All of the informants immediately felt the coming of danger and intuitively decided to move away from it. However, such a decision to flee was not actually individually taken. Fifteen informants said they had fled because they saw many people ran away from "something." Saputra (21 years, male) and Rida (22 years, female) said they heard people shouting repeatedly that seawater was rising. They saw many people ran to the opposite direction of the seashore. However, both Saputra and Rida did not realize immediately what was happening. A 58-year Anas also said he fled because he heard and saw many people ran away from the direction of the seashore. Using Paul Valent's categories of survival strategies and their appraisals, "fleeing" was the only strategy the Banda Aceh survivors made during the 2004 tsunami. There were cases in which the fleeing people also rescued other fellow residents. But these cases seem to be stimulated by a spontaneous and unintended decision. 


\section{Sendai Tsunami Survivors}

As mentioned earlier, the survivor of Sendai tsunami to whom the researcher talked, had experienced three different tsunamis before March 2011. She was Sayoko (about 45 years old, female), originally from Kamaishi in the Iwate Prefecture, a tsunami prone area in northeastern Japan. While driving her taxi that took us to the area of her former home in Sendai, in May 2013, Sayoko said that at the time the earthquake hit on 11 March 2011, she was driving with her grandmother on a toll road near her home in Sendai.

Sayoko said she knew she had to move to a mountainous or higher level area soon after she had felt the strong earthquake. Her feeling of haste was doubled as she also suddenly remembered the 1995 earthquake in Osaka, in which toll roads collapsed. Sayoko said she was feeling a great rush at that time, but did not panic. She was wondering whether the radio information she was listening was accurate because she saw so many people already fleeing and traffic jam was everywhere.

"It [the seawater] began to come into my car so that I immediately went out of the car while grasping my grandmother to go out too. I managed to climb on top of the car roof. The seawater was already $170 \mathrm{~cm}$ high. I reached a concrete bar beside a house, with my grandmother, and we sat on it. But the water level kept rising. There was a two-story house next to that house, so I managed to move to that house's second floor. When I tried to hold my grandmother's hand while moving to the house, she slipped on her feet so that I lost my grips on her hand. She was drowned on to the water, which had reached the height of about $2 \mathrm{~m}$ with strong stream. I lost my grandmother. I was very shocked but immediately realized that I had to keep moving to that house in order to get survived." (personal communication, May 2, 2013)
Sayoko's testimony reveals that knowledge and memories of past tsunamis did matter in the evacuate behaviors during the Sendai tsunami she was experiencing. With three times of previous tsunamis, Sayoko knew what to do immediately. She made a fleeing decision right after the earthquake hit. She knew where to go as to be saved although she found it not possible to go the direction she wanted to flee. She quickly changed her mind as to evacuate. She stayed calm and this helped her to keep thinking rationally amid the emergency situation.

The calm behavior that Sayoko demonstrated in facing and dealing with the danger of tsunami was widely shared in the case of Japan's March 2011 tsunami. In the three video recordings selected on purpose from YouTube, there were no people fleeing in panic although they were in very great haste. Unlike the narrative illustration of panicked flocks that the Banda Aceh tsunami survivors had told me in their case of self-evacuating, the majority of survivors caught in these videos looks quiet, which somehow indicates their customization of the tsunami disasters.

\section{Recording 1: "Japan tsunami 2011"}

The first video, entitled "Japan Tsunami 2011" by Friedman (2014) shows the development of situation following an earthquake along a riverbank in, unfortunately, an unnamed area in Japan. The video shows a view from what could be the third floor of a building where one elderly man and two women were standing and calmly watching the hard-flowing water. In a farther distance from the cameraman, there were many other people. Everybody shown in the video look calm and quiet, even when the water flow became extremely high and hard, and had reached the parking lot and yard in front of the building where these people were. No panic situation is shown. 


\section{Recording 2: "Japan Tsunami in Sendai.m4v"}

The second recording, entitled "Japan Tsunami in Sendai.m4v" by FrdTBO (2011) shows fragments of people's individual strategies of survival. In one shot, the camera spots a man sitting on top of a car, which was already stuck by some other cars. This man looked around so calmly. A minute later, he swam to cross the river-like road as to reach a two-story building opposite it. He did this successfully. In another fragment a man is shown still sitting behind the wheel of his car although the water level keeps increasing. When a big wave of the tsunami came, his car moves unsteadily and becomes rather twisted. There is sound coming from people on the pedestrian bridge, who seem to have watched the man in the car. The rest of the recording shows the hours after the shocking waves. It shows the many people who, together with the recording maker, evacuated on the pedestrian bridge. They all looked calm while they waited for a major evacuation, which only arrived at 2.20 am the next morning.

\section{Recording 3: “Japans Tsunami Caught on Camera"}

The third recording "Japans Tsunami Caught on Camera" by Prez (2011) shows the survivors' experience at the time of earthquake and during the tsunami in the areas of Kamaishi, Ofunato, Rikuzentakata, Kesennuma, Minamisanriku, and Tagajo. There were fifteen survivors giving interviews for this recording. Only two did not think immediately that tsunami would happen after they felt earthquake on March 11, 2011. One of the two said:

"I originally came from a hilly area and have no common sense a danger of tsunami would come after a strong earthquake. I eventually realized that tsunami was coming when I saw it. People came out of their cars, but I did not. Then my car was hit strongly by water. I thought
I was going to die. But I did not feel panicked myself. I was quite calm and thought it was the way it should be." (personal communication, December 13, 2011).

Meanwhile, one of the thirteen interviewees who were convinced that tsunami would come after they had felt strong earthquake, said:

"I was born a year after my parents lost a daughter - my elder sisterin the 1960 Chile tsunami. In my whole life I was told that I was born because my sister died in a tsunami. Every time I heard in all the regions loud alarm and announcement from fire trucks that kept warning people about the coming of tsunami." (personal communication, December 13, 2011).

\section{Discussion}

\section{The Construction of Tsunami-related} Memories

The survivor cohorts in Banda Aceh and Sendai performed various sorts of strategies to cope with the catastrophic event and its aftermath. However, they all shared a similar pattern of retrospective perspective of the two different tsunamis they had experienced. When, in 2013, asked how they remembered again the tsunamis they had experienced, all of them expressed a deep feeling of loss.

Generally, for the survivors of the March $11^{\text {th }}, 2011$ tsunami, a social loss remained to be considerable because of the missing family member. Sayoko felt shocked and depressed not because of the tsunami event but because she lost her grandmother. "It [to lose grandmother] was like the end of the world to me," she said. "I could have a new house and a new car after every tsunami I passed through, but I cannot have a new grandmother." The feeling of loss also became especially great because of the removal from the previous place of living to the present. Removal from the living place meant the uprooting of one's social establishment in 
Picture 2.

A concrete pillar of a building indicating the height of the 2011 tsunami water level in Sendai
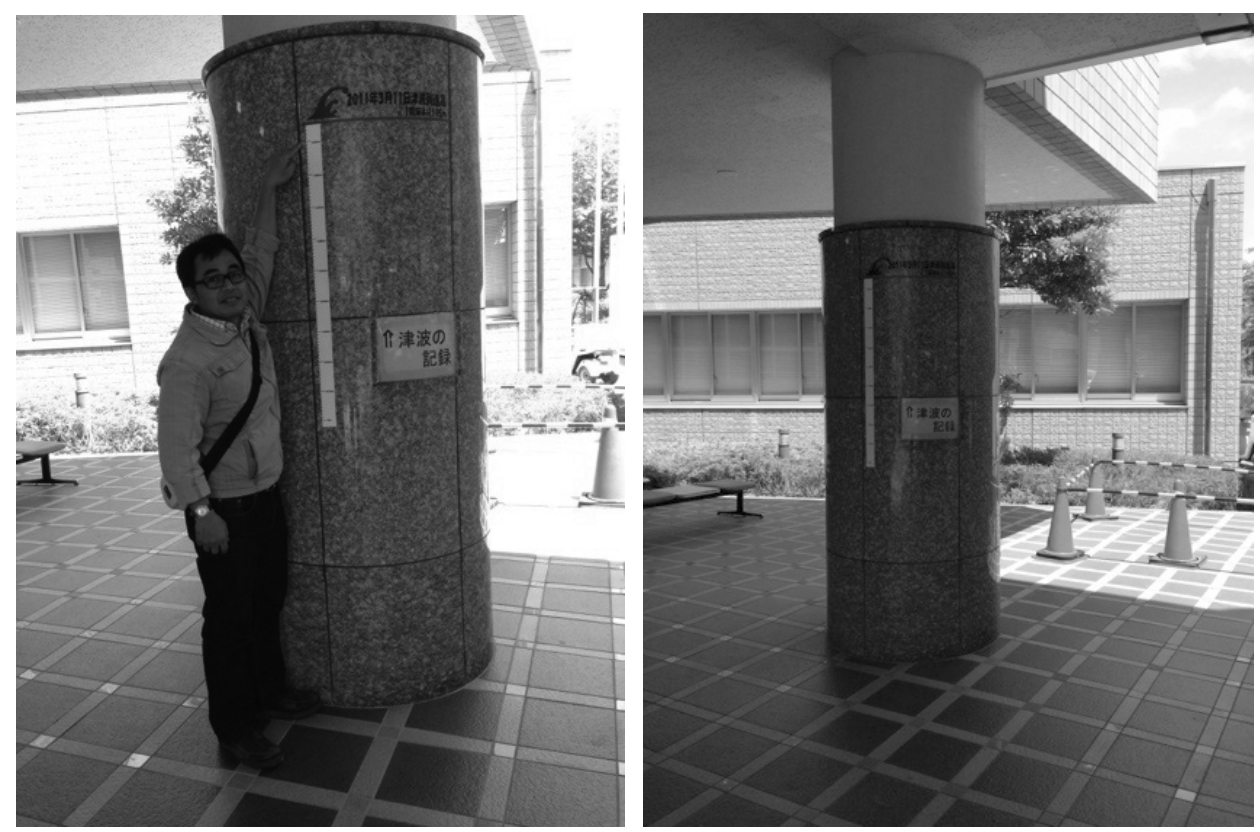

Source: Author documentation

a community. Banda Aceh survivors also felt great losses of family members, properties and belongings. In this situation, there was an element of religious beliefs that crucially helped both cohorts of survivors pass through the difficult moment.

In the Banda Aceh case, the negative feelings of losses, sadness and trauma seemed to have been absent, which is likely due to the improving economy after the tsunami. During the interview in 2013, some of the survivors said their life today (2013) was better economically than it had been before the tsunami. An improved economic condition hence helped them to survive the post-tsunami trauma and healed the losses they had suffered. But it worked only in the Banda Aceh case under study. For the Sendai case, no element of economic improvement is detailed in the acquired data.

\section{A religious element: Banda Aceh and Sendai}

The Banda Aceh survivors said their belief in the help of Allah, Good the Almighty, kept them surrendering to the condition after the tsunami and to accept it as a test from God on their faith. The survivors in Japan case said they relied on the help of God, ancestors' spirits, the government and neighborhood programs. Although there was a depressed and desperate feeling, the survivors in the case of Japan 2011 tsunami also voiced out great optimism for rebuilding a better life. Although not exclusively, they also continued to believe in the super-natural power that had saved them from the catastrophe.

Because they did not have prior knowledge on tsunami and therefore sporadically fled in panic and fear, some of the Banda Aceh survivors thought that the end of the world (hari kiamat) had come. One of them said:

"I really thought the end of the world had come. Houses and trees were uprooted, cars and roads destroyed. People fled in tremendous panic. I really thought the city of Banda Aceh would be completely swept and drowned by the seawater. I could only pray as I remembered what my religious teacher once had said that the end of the world would 
be marked by chaos and disorder." (personal communication, June 12, 2013).

On the contrary, some of the interviewed survivors said that it was not the end of world. For example:

"After I fled to the roof of a house, I could still see the top of Mount Mata'i. I immediately said to myself that it was not the end of the world. My religious teacher told me that the mountains would be uprooted should the Judgment Day have come." (personal communication, June 12, 2013).

These two opposite convictions helped those survivors of the Aceh tsunami face the chaotic situation during the days of the tsunami. Those who believed that it was the end of the world managed to submit themselves into prayers. Thus they became psychologically peaceful and relieved from a panic situation. Meanwhile, those who believed it was not the end of the world also became peaceful as they felt a growing energy of surviving.

Meanwhile a female survivor of the Sendai tsunami said she was saved by miracle.
She could not reach higher ground nearby her house before a high wave struck. She said a wave pushed a floating car, which to her looked as if it were her pick up.

Although they evacuated safely, most of the interviewees said they were shocked by the immense disaster the tsunami caused, for example Yasuo Kishi (male) and Hiroko Sugawara (female). Kenichi Murakami, a retired director of a fish processing plant, said the end of "Kesennum" had come as he saw fire everywhere in the evening after the tsunami. It was like being in hell, he said. Kumiko Suzuki thought the 2011 tsunami was retribution because God was angry. All these perspectives show depressed feelings.

There were survivors who kept optimistic views. Kenji Saito, owner of a sweet and cake business, said he had to stand "taller" in his business than before. Takuyuki Saijo, a tv-cable reporter, said that humans are strong. From the disaster he thought perhaps it was they who made a mistake, living in an area prone to tsunami.

All these different testimonies show different personal judgments and strategies that our informants underwent as to survive the tsunami. Some survivors were guided by an

Picture 3.

Baiturrahman Grand Mosque in Banda Aceh (built in 1292), believed by local Acehness to have been protected by God from the 2004 tsunami as the building construction stayed steady and water level reached only up to its floor during the catastrophe.

Photographed in 2013, no sign of tsunami water height level indicated
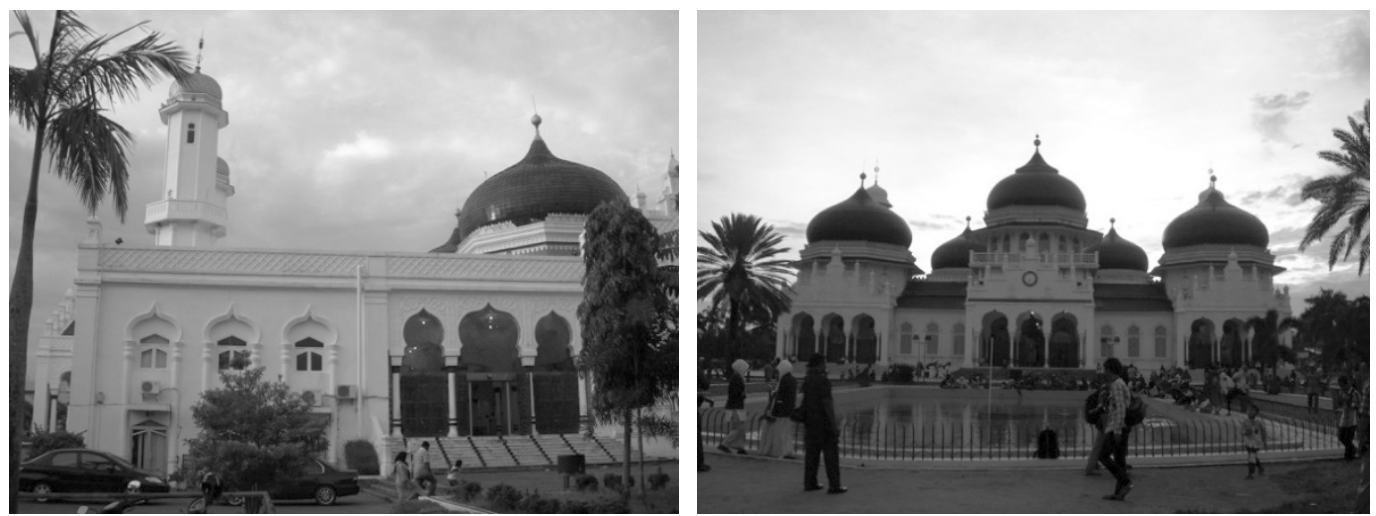

Source: Author documentation 
Picture 4.

A shrine as a tsunami memorial at the highest point of the 2011 catastrophe in Sendai. Height of water level indicated at the entrance pool (left)
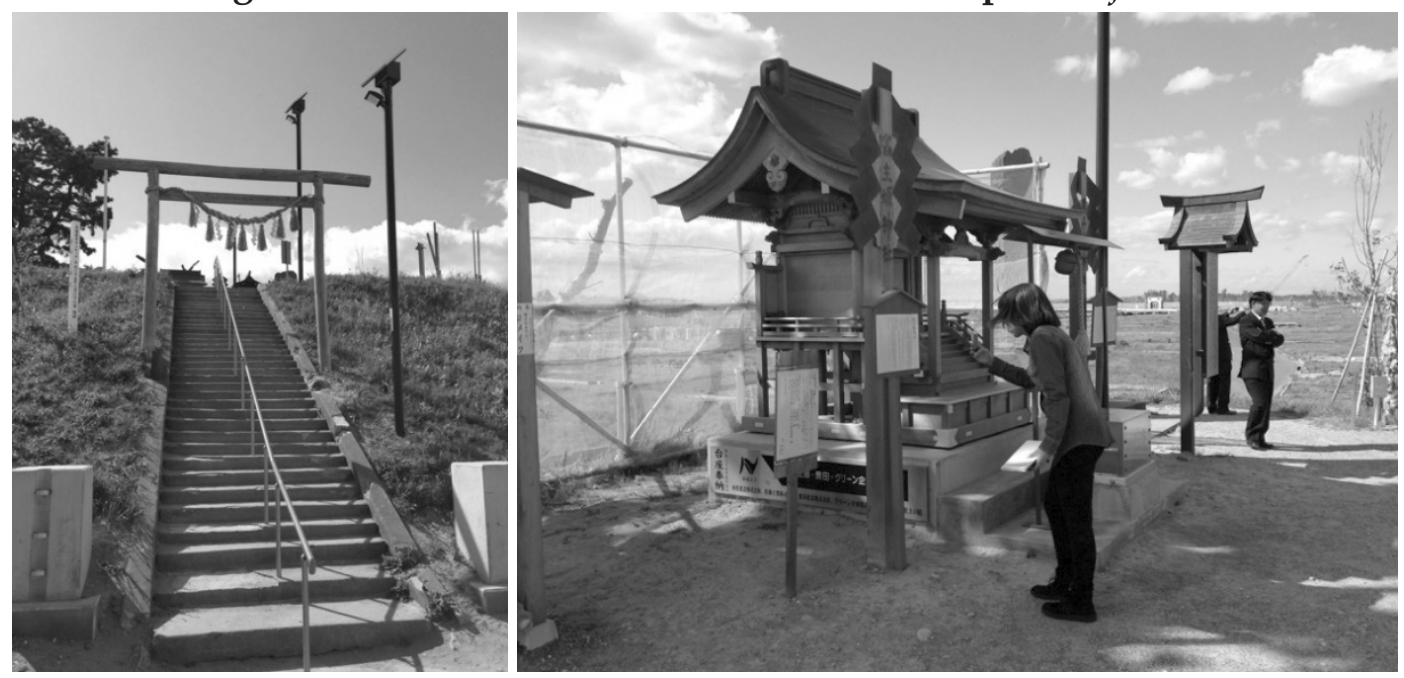

Source: Author documentation

instinctive pulse to move away from the danger and to get saved. Yet, instead of denying the coming of danger by simply following other people in panic without knowing what was going on, those who had got prior knowledge of tsunami showed an assertive behavior by somehow embracing the chaotic situation as to learn it. Only then they decided the fleeing goal to be achieved. These testimonies reveal complex appraisals but, considering the absence of prior knowledge on tsunami, also create sporadic and unprecedented patterns of survival that are not only individually but also socially rooted. This observation conforms Schlehe's conclusion that the survivors' explanations of a disaster are manifold as "they touch many aspects of a person (emotional, physical, rational, and spiritual) and they refer to the perception of contradictions and conflicts" (Schlehe, 2010, p. 19).

\section{An Economic Element: Banda Aceh}

Over the past eight years since the Aceh tsunami, some informants said they still had the trauma of the disaster. Amel, Armila, Saputra and Icih, for example, recalled the tragic days of the tsunami in fear and sadness until then.
For some other informants, however, the lapping time helped them to heal from the trauma. Soleh (55, male), who lost one of his legs, managed to understand what had happened in his life in a spiritual manner. Hasan (27) shared Soleh's view. He said, to surrender to God was the best way to face this tragedy.

Meanwhile, Rasyid (23, male) said the tsunami made a way for the Aceh people to see the true outside world (dunia luar yang sebenarnya). Rasyid answered that before the tsunami, Aceh was like an isolated area because of the Indonesian military operation against the Aceh Independent Movement (Gerakan Aceh Merdeka, GAM). Both sides signed a peaceful agreement not long after the tsunami.

Anas (21, male) said, regardless of his loss, he felt happy now because he had a brandnew car of his own. Before the tsunami, he said, there were only few brand-new cars on the streets in Banda Aceh. Now there were so many. Armila also saw her life better now than it had been before because she got a permanent employment at the local government office.

For the younger generation like Rasyid, Roni, Saputra, Hasan, and Akbar, who were all 
Picture 5.

Traditional and modernized coffee shops as a sign of economic improvement in post-tsunami Banda Aceh, photographed in May 2013
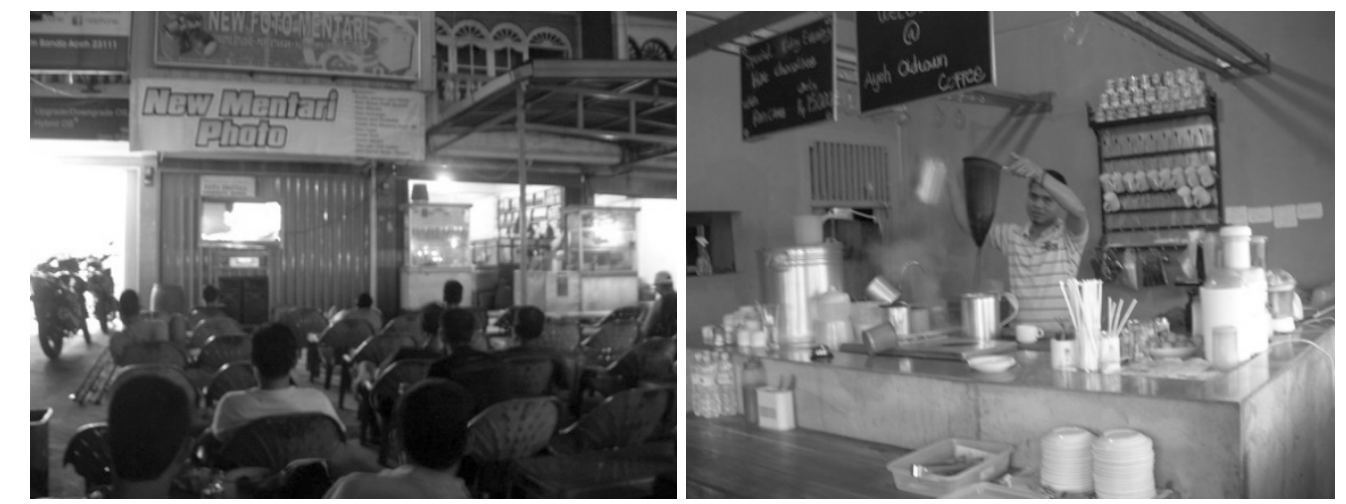

Source: Author documentation

teenagers at the time of tsunami, life after the tsunami was even much better than they had experienced before. All of them said they got scholarships to study up to higher education. Rida said her family got financial subsidy from the government until about five years after the tsunami. His brothers got a job at two different international NGOs. Roni added that today the public facilities in Banda Aceh were good: reconstructed roads with large pedestrian spaces, new buildings, new houses and public parks.

When we visited Banda Aceh in June 2013 we witnessed the happy life of young people. We identified that there were so many places to hang around for the young people. These places were commonly called "kedai kopi" (coffee shops). According to some people we talked to, the coffee shops had been there around Banda Aceh before the tsunami. But after the tsunami, the buildings of the coffees shops were also more spacious than before.

The coffee shops in Banda Aceh today provided free internet connection, which made it a particular place of attraction for the young people. Everywhere we went to the coffee shops in Banda Aceh we met many students in there. In the coffee shops that did not provide an internet connection, meanwhile, we always noted the presence of a wide-screen television showing movies or international programs. A barista of one coffee shop told us that people would not get attracted to visit his coffee shop if it did not provide either free internet connection or cable-tv entertainment. These coffee shops thus created a new life style and a new social space, especially for the young people.

\section{Conclusion}

The process of survival in the longer term vary among informants. Some informants chose to adapt to the situation and feeling of loss as they surrendered themselves to the condition they were facing. Some others took an assertive attitude towards the disaster by striving for a positive way of thinking and perspective; thus they became optimistic about their life after the tsunami. In both of these strategies (adapting and asserting), religious beliefs played a crucial role. In addition to adapting and asserting, fighting was another strategy that some of our informants chose as a way to overcome the feelings of loss, trauma and depression. They fought against these feelings of despair by moving away from the haunting memory of disaster experience.

In all these cases of survival strategies, the role of both internal and external factors was evident. The internal factors include the degree of tsunami exposure during the event. 
Greater loss did not necessarily mean greater depression because other aspects of internal factors, for example, individual attachment and understanding of religious beliefs, also played a role. The external factors include psychological, social, and material/financial supports from families, neighbors, social organizations, the governments and the international community. For the longer term of recovery, however, the most effective external factor would be to create a new social space.

Scheme of cooperation between Japan and Indonesia can be formulated in the form capacity building through the preservation of local knowledge of tsunami-related survival strategies. It can take the forms of either Japan's outreach program to Indonesia at the peopleto-people platform or a joint-network of civil society organization on tsunami risk reduction advocacy programs. In Japan, institutional recovery programs had been developed to facilitate people with the survival strategy options. The implementation of integrated programs of surviving strategies in which local social network of tsunami-related information distribution is a key. In Indonesia, although some tsunami warning monuments were erected throughout the city of Banda Aceh in commemoration of the 2004 tsunami, the programs that were directed to strengthen the capacity of local social networks and to preserve the local knowledge of survival strategy are still absent. At this point, a scheme of cooperation may also include identification of the history of tsunami in local terms, both in Japan and in Indonesia. It is also important to deal with sophisticated knowledge and vernacular knowledge that has existed in the society.

\section{Acknowledgments}

The research leading to this article was funded by The Sumitomo Foundation's Japan-related Scheme Grant 2013. The author would like to express his deep gratitude to the Sumitomo Foundation. Special thanks also go to Sayuri Tosha, Imamura Hiroyuki, Satrio Dwi Cahyo and Yayum Kumai (then, successively, Graduate School of Arts and Sciences The University of Tokyo, Master's Program at the Department of Anthropology Chuo University, Undergraduate Program at the Department of History University Gadjah Mada) for their assistantship in collecting data in Sendai and in Banda Aceh. Earlier versions of this paper were presented at the Southeast Asian Studies Colloquium, The University of Freiburg, Germany, December 2, 2017 and at the Taiwanese Sociological Association Annual Conference, Taipei November 30, 2019. For the presentation opportunities, the author would like to thank Prof. Judith Schlehe of the University of Freiburg Department of Anthropology and Prof. Jian-Bang Deng of the Tamkang University of Taiwan Department of Future Studies.

\section{References}

Arif, A. (2012, November 21). Mendidik sadar becana lewat komik. Kompas, p. 14

Chandler, S. (2005). Oral history across generations: Age, generational identity and oral testimony. Oral History 33(2), 48-56.

Dudley, W, Goff, J., Chagué-Goff, C., \& Johnston, J. (2009). Capturing the next generation of cultural memories: The process of video interviewing tsunami survivors. Science of Tsunami Hazards 28(3), 159-170.

Ehrentraut, S. (2010). Dividing Aceh? Minorities, partition movements and state-reform in Aceh Province. SSRN. Retrieved from https:// ssrn.com/abstract=1716587.

Fackler, M. (2011, April 20). Tsunami warning, written in stones. Retrieved October 4, 2019, from https://www.nytimes. com/2011/04/21/world/asia/21stones. html. 
FrdTBO, Chaîne de. (2011, October 8). Japan Tsunami in Sendai [Video file]. Retrieved February 1, 2015, from https://www. youtube.com/watch? $\mathrm{v}=\mathrm{qO}$ OlL2kbKGFQ.

Fitzpatrick, D. (2008). Women's right to land and housing in tsunami-affected Aceh, Indonesia. Retrieved from http://www. ari.nus.edu.sg/docs/downloads/aceh-wp/ acehwps08_003.pdf.

Friedman, J. (2014, January 10). Japan's tsunami 2011 [Video file]. Retrieved February 1, 2015, from https://www.youtube.com/ watch? $\mathrm{v}=\mathrm{KCfzMG}-\mathrm{HBCk}$.

Gaillard, J.C. \&Texier, P. (2010). Religion, natural hazards, and disasters: An introduction. Religion 40, 81 - 84. doi: 10.1016/j.religion.2009.12.001.

Hidayat, R. (2019). Public distrust and environmental citizenship: Primary impetuses of radical protest in Bima District 2011-2012. Jurnal Ilmu Sosial dan Ilmu Politik, 23(3), 187-200. doi: 10.22146/ jsp.35981.

Iemura, H., Takahashi, Y., Pradono, M. H., Sukamdo, P. \& Kurniawan, R. (2006). Earthquake and tsunami questionnaires in Banda Aceh and surrounding areas. Disaster Prevention and Management, 15(1), 21-30. doi: $10.1108 / 09653560610654211$.

Kawato, Y., Pekkanen, R., \& Tsujinaka, Y. (2012). Civil society and the triple disasters: Revealed strengths and weaknesses. In J. Kingston (Ed.), Natural disaster and nuclear crisis in Japan: Response and recovery after Japan's 3/11 (pp. 78-93). Oxon: Nissan Institute/Routledge Japanese Studies Series. Kingston, J. (2012). Introduction. In J. Kingston (Ed.), Natural disaster and nuclear crisis in Japan: Response and recovery after Japan's 3/11 (pp. 1-11). Oxon: Nissan Institute/ Routledge Japanese Studies Series.

Kjaergaard, E. (2015). Child center disaster risk reduction in South Asia: Basic Concepts. Kathmandu: UNICEF Regional Office for South Asia. Retrieved from http://
ndmc.gov.mv/assets/Uploads/48413childcentereddrrsouthasia2015.pdf.

Kohlstedt, K. (2016, August 15). Tsunami stones: Ancient Japanese markers warn builders of high water. Retrieved October 4, 2019, from https://99percentinvisible.org/ article/tsunami-stones-ancient-japanesemarkers-warn-builders-high-water/

Lestari, P., Paripurno, E.T., \& Nugroho, A. R. B. (2018). Disaster risk reduction based on community through contigency plan for Mount Sinabung. Jurnal Ilmu Sosial dan Ilmu Politik, 21(3), 231-245. doi: 10.22146/ jsp.30059

McAdoo, B.G., Dengler, L., Prasetya, G., \& Titov, V. (2006). Smong: How an oral history saved thousands on Indonesia's Simeulue Island during the December 2004 and March 2005 tsunamis. Earthquake Spectra, 22(3), 661-669. doi: 10.1193/1.2204966

Merli, C. (2010). Context-bound Islamic theodicies: The tsunami as supernatural retribution vs. natural catastrophe in Southern Thailand. Religion 40, 104-111. doi: 10.1016/j.religion.2009.12.003

Miller, M. A., \& Bunnel, T. (2011). Post-disaster urban renewal: Memories of trauma and transformation in an Indonesian city. Asia Research Institute. Retrieved from http:// www.ari.nus.edu.sg/wps/wps11_154.pdf.

N.N. (2012, October 12). Pendidikan Bencana Lewat Manga. Kompas, p. 14.

N.N. (2013, March 11), Pelajaran dari Tsunami Jepang, Kompas, p. 10.

Neumayer, E., \& Plümper, T. (2007). The gendered nature of natural disasters: the impact of catastrophic events on the gender gap in life expectancy, 19812002. Annals of the Association of American Geographers, 97(3), 551-566.

Octastefani, T., \& Rum, M. (2019). Millennials' contribution in disaster risk reduction: Case study of tidal flooding in Semarang. Jurnal Ilmu Sosial dan Ilmu Politik, 23(1), 14-29. doi: 10.22146/jsp.43727 
Prez, T. (2011, December 13). Japan's tsunami caught on camera [Video file]. Retrieved February 1, 2015, from https://www. youtube.com/watch?v=oArd_9uZOnE.

Rahman, A., Sakurai, A., \& Munadi, K. (2018). The analysis of the development of the Smong story on the 1907 and the 2004 Indian Ocean tsunamis in strengthening the Simeuleu island community's resilience. International Journal of Disaster Risk Reduction, 29, 13-23. doi: 10.1016/j. ijdrr.2017.07.015.

Reid, A. (2016). Two hitherto unknown Indonesian tsunami of the seventeenth century: Probabilities and context. Journal of Southeast Asian Studies, 47(1), 88-108. doi: $10.1017 / S 002246341500048 X$

Rofi, A., Doocy, S,. \& Robinson, C. (2006). Tsunami mortality and displacement in Aceh province, Indonesia. Disasters, 30(3), 240-250. doi: 10.1111/j.03613666.2005.00324.x

Samek, J. H., Skole, D. L., \& Chomentowski, W. (2004). Assessment of impact of the December 26, 2004 tsunami in Aceh Province Indonesia. Center for Global Change and Earth Observations. Retrieved from http:// www.landsat.org/trfic/tsunami2004/ Assessment_of_Tsunami04.pdf.

Schlehe, J. (2010). Anthropology of religion: Disasters and the representations of traditions and modernity. Religion, 40, 112-120. doi: 10.1016/j.religion.2009.12.004

Shibata, A. (2012). Importance of the inherited memories of great tsunami disasters in natural disaster reduction. In Proceeding of the International Symposium on Engineering Lessons Learned from the 2011 Great East Japan Eartquake. Tokyo, March 1-4.

Sugimoto, M., Iemura, H., \& Shaw, R. (2010). Tsunami height poles and disaster Awareness: memory, education and awareness of disaster on the reconstruction for resilient city in Banda Aceh, Indonesia. Disaster Prevention and Management, 19(5), 527-540. doi: 10.1108/09653561011091869 Tedbudiyansah. (2013, December 24). Ibena. Retrieved from http://tedbudiyansyah. tumblr.com/post/71016145463/ibenasalah-satu-istilah-yang-telah-ada-dalam.

UNDRR [United Nations Office for Disaster Risk Reduction]. (2012, October 2225). 5AMCDRR: 5th Asian ministerial conference on disaster risk reduction. Retrieved from https://www.unisdr.org/ we/inform/events/23540.

Valent, P. (1998). From survival to fulfillment: A framework for the life-trauma dialectic. Philadelphia: Bruner/Mazel. Retrieved from http://www.trauma-pages.com/a/ valent98.php, p. 4.

Veras, J. H., Taniguchi, T., Jaller, M., Aros-Vera, F., Ferreira, F., \& Thompson, R. G. (2014). The Tohoku disasters: Chief lessons concerning the post disaster humanitarian logistics response and policy implications, Transportation Research Part A: Policy and Practice, 69(Nov), 84-108. doi: 10.1016/j. tra.2014.08.003. 